\title{
Influence and Influenced Between Self-Efficacy and Principal Leadership: A Systematic Review
}

\author{
Tubagus Ali Rachman Puja Kesuma ${ }^{*}$, Sudjarwo ${ }^{2}$, Pargito $^{2}$, Ridwan Ridwan ${ }^{3}$, Rias Tusianah ${ }^{4}$, \\ Usastiawaty C.A.S Isnainy ${ }^{5}$, M. Arifki Zainaro ${ }^{5}$, Albet Maydiantoro ${ }^{2}$, Edy Irawan ${ }^{6}$ \\ ${ }^{1)}$ IAIN Metro, Metro City, Lampung Province, 34111, Indonesia. \\ 2) Universitas Lampung, Bandar Lampung, Lampung Province, 35141, Indonesia. \\ ${ }^{3)}$ SMPN 3 Way Pengubuan, Lampung Tengah District, Lampung Province, 34164, Indonesia. \\ ${ }^{4)}$ SMPN 2 Seputih Agung, Lampung Tengah District, Lampung Province, 34162, Indonesia. \\ ${ }^{5)}$ Universitas Malahayati, Bandar Lampung, Lampung Province, 35153, Indonesia. \\ 6) Universitas Muhammadiyah Pringsewu, Pringsewu District, Lampung Province, 35373, Indonesia. \\ * Corresponding Author: tubagus.ali.rachman@metrouniv.ac.id
}

Received: May 31, 2021. Revised: July 14, 2021. Accepted: July 16, 2021. Published: July 20, 2021.

\begin{abstract}
This literature review article aims to look at the variables that influence, are influenced, and mediated by the leadership practices of principals in schools. The authors reviewed 16 research articles from European countries and a small part of Asia and America. The researchers concluded that: 1) Self-efficacy can affect variables such as emotional exhaustion, job satisfaction, normative commitment, and including motivation not to resign. 2) Self-efficacy can fluctuate, influenced by experience, which at that time can also be influenced by the opinions of others. Therefore, a leader is responsible for the development and growth of job satisfaction and teacher self-efficacy. 3) Self-efficacy can be a mediator for the growth and development of other variables. The psychological atmosphere you feel at that moment also adds another variable. The self-efficacy variable can also determine the improvement and achievement of other variables. This study provides new insights into how to manage people for maximum results.
\end{abstract}

Keywords- Principal Leadership, Self-Efficacy, Systematic Review.

\section{INTRODUCTION}

$\mathrm{S}$ elf-efficacy make reference to belief in a individual competence to manage and act necessary to achieve what is mandated [1]. Self-efficacy is a greatly studied increase that has been segmented into sundry cognitive motivation theories including attribution theory, expectation value theory, and goal theory [2]. In educational conditions, teacher selfefficacy trusts have been establish to perform a crucial character in the achievement of student outcomes (e.g., accomplishment and motivation) and teachers (e.g., motivation and successful teaching technique) [3-5]. Bandura [6] as hypothesized four main origins that contribute to self-efficacy: capability involvement in, representative involvement in, verbal persuasion, and affective states. Educational researchers agree broadly that research exploring the origins of educator self-efficacy is important because they construct knowledge about teacher-efficacy formation [7].

Self-efficacy will contribute to the well-being of an institution, namely an effective school. The literature on educational institution effectiveness more the last few ten years has providing that proof manifest that principal leadership plays an important part in school achievement. Researches declare that leadership practices, whatever the style, such as an effective distributed and instructional leadership style can bolster students learning, even however the influence is indirect. Leadership supports student achievement through its straight effects on climate, construction, civilization, values, and teachers [8-10]. School leadership in general influences through its influence on people and processes so that college chiefs can straightly effect educators' trusts, felling, and daily activities. For example, experimentation that investigates whether and to what level school management is able to quantify the kinds with regard to work happiness and perceptions of self-efficacy [11-18]. This research, in essence, states that there is a direct and absolute connection between management and educators outcomes.

Variables such as culture and school conditions, teacher 
collaboration are considered as important shaping factors for schools because they facilitate educators to unlock classrooms, criticize problems related to the teaching and learning process, and contributions design to make better pedagogy practice and outcomes [19]. There is proof that expert teamwork between educators is possible to increase educator self-efficacy $[12,20$, 21] and job satisfaction [22]. In addition, experiences in an conditions of mutual esteem and hold up are possible to proffer and increase educators' belief, bravery and proportions to have an affair with problems related to teaching and learning between bolster from all parties, especially peers and open discussion [23]. A responsive to school practice with personnel who regard each other enhances the school as a safe environment [24]. In a absolute neighborhood where educators can study from everyone with respect the result is that educators are over capable of accomplishing (contented), and their will continue to make better their pedagogy practices. In short, these variables influence the perceptions of the selfefficacy of the people involved. Given the lack of literature review on the interrelationship among self-efficacy and selfefficacy of leaders, we quest to understand the constructs of Self-efficacy and Principal Leadership.

This article is motivated by the fact that it is still rare for authors to review self-efficacy that self-efficacy can influence and be influenced by. In general, researchers have only studied the self-efficacy variables affecting other variables. and no one has summarized that self-efficacy can affect and be influenced.

\section{LITERATURE REVIEW}

\section{Self-efficacy}

Self-efficacy is usually explained as a mental spirit to be confident that one is capable of completing a venture. Anyone who has nice self-efficacy shall also lean to have kind stimulation. On the different hand, anyone who has low selfefficacy will also have cheap morale. A person who believes that he or she is unable to complete a task will affect motivation and subsequent involvement in completing the task [25]. Bandura [1] appointed that self-efficacy is the faith in people who possess the ability to do certain jobs. It is also explained as learners' beliefs about their independent academic abilities. Pajares [26] described that self-efficacy can affect students' cognition, motivation, successful activities, and conduct. Therefore, in the pedagogy and learning procedure, self-efficacy plays an main role in regulating student conduct to achieve learning stride. Self-efficacy shoots a part in the self-regulation process that can psychologically influence students' choices to complete jobs.

In line with Bandura, Pintrich and De Groot [27] said that self-efficacy is a self-assessment of ones' abilities whose is the basis for self-belief and stimulation to be excellent in their assignments. Self-efficacy is influenced by four elements: last experiences of achievement and default, experiences of representation or designing, where watching a pair's achievement and default service to escalate or mitigate selfefficacy, communal inducement (boost or hopelessness) of others, people's beliefs on their abilities [1].

\section{Leaders' self-efficacy}

The construct of self-efficacy is considered extensively for a period of ten years by researchers in schooling $[28,29]$ and outside education $[30,31]$ and has been recognized as one of the principal internal elements affecting individual and organizational level outcomes [28, 31]. For example, a study in schools shows that educator self-efficacy is certainly related to their exhibition [32], student outcomes [33], parental support [34], and motivation. Self and job satisfaction [35]. While this research pathway focuses primarily on student selfefficacy, teachers in tenure and tenure, and principals, great little practical research to date has inspected the response of self-efficacy of team managements across districts counting supervisors, managers, and site principals [36]. Therefore, it is significant to complete this science space by investigating the self-efficacy of the management group, as the control group works as the engine of a switch innovation enterprise across districts [37, 38].

Organizations that have effective and adaptable leaders are believed to be further likely to manage in a quickly transformation neighborhood [39, 40]. In academic management, most research on principal self-efficacy center on outer behaviors or practical features of manager's selfefficacy such as leadership and managerial expertise [28, 29, $41,42]$. Whilst this features are principal, the capability to guide innovation and begin change may depend sorely on the inner capacities of academic principals as their try to near up by innovative plan for instructional alteration [43].

Self-efficacy is established as the stage to who's a person recognizes his competency, what can influence his studying and eventually individual exhibition [44]. That is, person attitude is studied and society appraise and change their behavior and cognitive operation to conform to the environment through experiences and interactions with the neighborhood [39]. There are two intact notions of selfefficacy that can be drawn from communal studying assumption: (a) self-efficacy is connected to the stage of means and enterprise that a person puts on a job, and thus connected to the stage of one's work attachments, and (b) self-efficacy is promoted by way of observation and interaction with another based on person's choices [27, 45, 46].

\section{Job Involvement and Self Efficacy}

Self-efficacy is able to develop. The expansion of selfefficacy is affected by one's previous experiences and is stored as preexisting knowledge and events that are perceived as communal bolster accepted by others that occur in the surrounding neighborhood [47]. When someone participates in an activity, their level of involvement is related to the conditional elements from which they get sign that indicate the successfulness of their exhibition. Self-motivation is promoted and increased when persons feel that their competence to make tasks increases and they become more competent in achieving specified goals [47]. Once society are moved, they are more ready to be involved in the task, and in go around, their feel of self-efficacy is further possible to be certainly effected. This is especially the matter when society is given recent assignments for which they have delimited references to previous experiences. persons obtain motion through the engagement 
procedure to assist extend their feel of motivation from which they form trusts on their ability to perform tasks [48]. Highly motivated people are more possible to maintain a top-level of involvement in a mission for a greater spell of period than someone who is scantly encouraged, and so the people are more likely to get the destinations [48]. Hence, degree of involvement works for a significant factor of self-efficacy development.

The idea of engagement has been learned in business, psychology, and education and is connected with selfmotivation $[49,50]$. Although there is no as usual used clarity or general construction that defines the construct, it is usually approved that involvement is related to the existence of study of mental processes and mental states as a person makes organizational jobs [51]. Therefore, we construct engagement as comprising two main extends: cognitive engagement (a person's readiness to be on duty towards the achievement of purposes) and behavioral engagement (one's steps in reaching purposes).

Cognitive engagement requires a person's cognitive investment in studying together with framing the effort obligatory to understand the task [52]. Behavioral engagement deals with the doings and applications required for engagement in carrying out a specific goal-oriented mission [53]. Occupied works trend to work at high grades as they be convinced by their job has significance [54]. Additionally, they are over ready to invest time in their work and are not so much possible to impression employment burnout. Conversely, uninvolved worker tends to show a deficiency of true concern, and over possible to impression self-hesitation in effectively taking out institutional characters [51]. The involved worker can study through, and be promoted with, conditional cues/effects such as purpose setting and receive explanation and exhibition reaction in the environment [47]. Hereinafter, this output and feedback configuration their competence to make organizational characters that are significant to them [55], which in turn facilitates their perfection of self-efficacy [48]. Given the characters of job involvement in the cultivation of self-efficacy and the restricted study accessible in academic management, our question is, "What are the results of the research on self-efficacy in the countries studied?".

Communal system assumption is interested in the designs of relations among stagers like personals, classes, organization, and the outcoming system positions of stagers like an inner, outlying, mediator [56, 57]. A community network be composed of a set of stagers and the relatively relationships among the stagers that explain the system [58]. The position of actor-network is determined by the design of relatively bonds that actors in the network have [57, 59]. Social networks could be utilized to establish the communal assests of single actors $[60,61]$. This idea is built on the academic assumption that relatively funds are invested in communal relationships among stagers in-network constructs and can be collected and throw across networks to develop the possibility of achievement in work [59, 61]. This social capital network perspective also discusses the contract of communal connections that encircle stagers and the outcoming network positions of personal actors who can bolster or limit the stream of resources between these stagers [62, 63]. In general, networking experts posit that tightly connected network structures can make it easy/easier or limit the entrance and period of news and the stream of communal assets over systems [59]. whilst a compact network contexture allows resources to travel efficiently over the system, it can also make easy and amplify resources that bring affectless such as gossip, hostility, and mistrust [64].

\section{METHODOLOGY}

Aim of the study

This review literature article aims to see:

1. What does Self-Efficacy affect in terms of leadership?

2. What influences self-efficacy within the framework of leadership practice?

3. What is self-efficacy of mediation in terms of leadership practice?

\section{Method}

This literature review article is sourced from articles stored in Google Scholar. Articles that are deliberately collected are those published in 2020. Search for articles with the programmable search engine on Google Scholar by entering the words principals' leadership and self-efficacy. The author deliberately limits his search for associations with the words principals' leadership and self-efficacy from page one to page 10 only. Collected articles can be in the form of research articles, dissertations, and proceedings carried out in a research frame by ignoring qualitative or quantitative types while ignoring regional representation. The table below shows the search results.

Table 1 Search ranges in Google Scholar

\begin{tabular}{lllll}
\hline No & Search Engine & Pages & Years & Total \\
\hline 1 & Google scholar & $1-10$ & 2020 & 59 \\
\hline
\end{tabular}

Source: Data Analysis 2021

Furthermore, the authors conducted a filter. The author focuses only on quantitative research. The author excluded two articles because they were qualitative so only 57 articles were really quantitative articles.

\begin{tabular}{ccccccc}
\multicolumn{6}{c}{ Table 2 Google Scholar Search Results } & \\
\hline No & $\begin{array}{l}\text { Search } \\
\text { Engine }\end{array}$ & Pages & Years & Total & Qualitative & Quantitative \\
\hline 1 & $\begin{array}{l}\text { Google } \\
\text { scholar }\end{array}$ & $1-10$ & 2020 & 59 & 2 & 57 \\
\hline
\end{tabular}

Source: Data Analysis 2021

Furthermore, the authors conducted further screening with a focus on the words self-efficacy and school. The purpose of focusing on the word aims to examine the word self-efficacy (variable self-efficacy) to be examined by juxtaposing it with any variables. By looking at the various variables juxtaposed, it can be seen how extensive the impact of the self-efficacy variable is.

Table 3 Screening Results by Topic

\begin{tabular}{|c|c|c|c|c|c|}
\hline No & Search & Pages on Google & Years & Total & Qualitative \\
\hline
\end{tabular}


INTERNATIONAL JOURNAL OF EDUCATION AND INFORMATION TECHNOLOGIES

\begin{tabular}{|c|c|c|c|c|c|c|c|}
\hline & Engine & scholar & & & 6 & Almuta & Leadership \\
\hline 1 & $\begin{array}{l}\text { Google } \\
\text { scholar }\end{array}$ & $1-10$ & 59 & 2 & & $\begin{array}{l}\text { i58 } \\
{[70],}\end{array}$ & $\begin{array}{l}\text { Self-Efficac } 2 \\
\text { and }\end{array}$ \\
\hline & : Data & sis 2021 & & & & Arabia & 1 \\
\hline
\end{tabular}

Pearson

product correlation coefficient, with 400

faculty member as the samples

Table 4 The results of checking the variables juxtaposed with self-efficacy

\begin{tabular}{|c|c|c|c|c|}
\hline No & $\begin{array}{l}\text { Author, } \\
\text { Year, } \\
\text { Country }\end{array}$ & $\begin{array}{l}\text { Research } \\
\text { Topic }\end{array}$ & Method & $\begin{array}{l}\text { Important point of } \\
\text { Research }\end{array}$ \\
\hline 1 & $\begin{array}{l}\text { Zhang, } \\
\text { Yin } \\
{[65],} \\
\text { China }\end{array}$ & $\begin{array}{l}\text { The effects of } \\
\text { proficiency } \\
\text { studying } \\
\text { society on } \\
\text { educator's } \\
\text { self-efficacy } \\
\text { and job } \\
\text { satisfaction }\end{array}$ & $\begin{array}{l}\text { Survey with } \\
982 \text { samples }\end{array}$ & $\begin{array}{l}\text { Characteristics of } \\
\text { proficiency studying } \\
\text { society: shared inquiry } \\
\text { and shared goals and } \\
\text { responsibilities affect } \\
\text { teacher efficacy and } \\
\text { learning strategies } \\
\text { positively and } \\
\text { significantly }\end{array}$ \\
\hline 2 & $\begin{array}{l}\text { Liu, } \\
\text { Belliba } \\
\text { ș [66], } \\
\text { Turkey }\end{array}$ & $\begin{array}{l}\text { Instructional } \\
\text { Leadership } \\
\text { and } \\
\text { Distributed } \\
\text { Leadership on } \\
\text { Teacher Self- } \\
\text { efficacy and } \\
\text { Job Effect }\end{array}$ & $\begin{array}{l}\text { SEM Survey } \\
\text { with } 104,358 \\
\text { teachers from } \\
6045 \text { schools } \\
\text { in } 32 \\
\text { countries as } \\
\text { the samples }\end{array}$ & $\begin{array}{l}\text { Distributed leadership } \\
\text { and instructional } \\
\text { leadership are both } \\
\text { positively and directly } \\
\text { related to teacher job } \\
\text { satisfaction and teacher } \\
\text { self-efficacy. } \\
\text { Meanwhile, distributed } \\
\text { leadership is positively } \\
\text { and indirectly related to } \\
\text { teacher job satisfaction } \\
\text { and self-efficacy. }\end{array}$ \\
\hline 3 & $\begin{array}{l}\text { Meyer, } \\
\text { Richter } \\
{[67],} \\
\text { Germa } \\
\text { ny }\end{array}$ & $\begin{array}{l}\text { Principal } \\
\text { leadership } \\
\text { and teacher } \\
\text { collaboration } \\
\text { relationship }\end{array}$ & $\begin{array}{l}\text { Survey cross- } \\
\text { sectional, } \\
\text { with } 630 \\
\text { teachers in } 29 \\
\text { primary and } \\
\text { secondary } \\
\text { schools as the } \\
\text { samples }\end{array}$ & $\begin{array}{l}\text { Based on structural } \\
\text { equation modeling, the } \\
\text { principal's leadership } \\
\text { has a significant indirect } \\
\text { effect on teacher } \\
\text { collaboration, mediated } \\
\text { by teacher collective } \\
\text { efficacy. }\end{array}$ \\
\hline 4 & $\begin{array}{l}\text { Phyu, } \\
\text { Khin } \\
{[68],} \\
\text { Myan } \\
\text { mar }\end{array}$ & $\begin{array}{l}\text { Principal } \\
\text { Leadership } \\
\text { Style, Teacher } \\
\text { Self-Efficacy }\end{array}$ & $\begin{array}{l}\text { SPSS version } \\
\text { 22, Pearson } \\
\text { correlation } \\
\text { ANOVA } \\
\text { descriptive } \\
\text { statistics, } \\
\text { with } 211 \\
\text { teachers as } \\
\text { the samples }\end{array}$ & $\begin{array}{l}\text { It was found that } \\
\text { teachers have a high } \\
\text { level of teacher self- } \\
\text { efficacy. There is a } \\
\text { statistically significant } \\
\text { relationship between } \\
\text { transformational } \\
\text { leadership style and } \\
\text { teacher self-efficacy and } \\
\text { between transactional } \\
\text { leadership style and } \\
\text { teacher self-efficacy. }\end{array}$ \\
\hline 5 & $\begin{array}{l}\text { Heraw } \\
\text { ati and } \\
\text { Tjahjo } \\
\text { no } \\
\text { [69], } \\
\text { Indone } \\
\text { sia }\end{array}$ & $\begin{array}{l}\text { Instructional } \\
\text { Leadership on } \\
\text { Professional } \\
\text { Competence } \\
\text { Mediated by } \\
\text { Self-Efficacy } \\
\text { and Social } \\
\text { Capital } \\
\end{array}$ & $\begin{array}{l}\text { Literature } \\
\text { review, with } \\
106 \text { articles } \\
\text { as the } \\
\text { samples }\end{array}$ & $\begin{array}{l}\text { Proposition 2: Self- } \\
\text { efficacy mediates the } \\
\text { influence of } \\
\text { instructional leadership } \\
\text { on professional } \\
\text { competence. }\end{array}$ \\
\hline
\end{tabular}

\begin{tabular}{|c|c|c|c|c|}
\hline 7 & $\begin{array}{l}\text { Harriso } \\
\mathrm{n}[71], \\
\text { USA }\end{array}$ & $\begin{array}{l}\text { Self-Efficacy } \\
\text { of Black } \\
\text { Female } \\
\text { Leaders, } \\
\text { Turnaround } \\
\text { Schools, } \\
\text { Organizationa } \\
1 \text { Systems } \\
\end{array}$ & $\begin{array}{l}\text { Semi- } \\
\text { structured } \\
\text { interview } \\
\text { Qualitative }\end{array}$ & $\begin{array}{l}\text { The goals of the } \\
\text { recommended } \\
\text { organizational support } \\
\text { should align with and } \\
\text { support the self-efficacy } \\
\text { of black female } \\
\text { principals leading the } \\
\text { turnaround. }\end{array}$ \\
\hline 8 & $\begin{array}{l}\text { Luo, } \\
\text { Foo } \\
\text { Seong } \\
\mathrm{Ng} \\
{[72],} \\
\text { Singap } \\
\text { ore }\end{array}$ & $\begin{array}{l}\text { Transformatio } \\
\text { nal } \\
\text { leadership, } \\
\text { teacher } \\
\text { outcomes }\end{array}$ & $\begin{array}{l}\text { Measurement } \\
\text { s of people } \\
\text { were obtained } \\
\text { in Rasch's } \\
\text { analysis, with } \\
495 \text { teaches } \\
\text { as the } \\
\text { samples. }\end{array}$ & $\begin{array}{l}\text { Transformational } \\
\text { leadership is positively } \\
\text { associated with teacher } \\
\text { mastery goals and self- } \\
\text { efficacy, both of which } \\
\text { partially mediate the } \\
\text { relationship between } \\
\text { transformational } \\
\text { leadership and teacher } \\
\text { outcomes. }\end{array}$ \\
\hline 9 & $\begin{array}{l}\text { Skaalvi } \\
\text { k [73], } \\
\text { Norwa } \\
\text { y }\end{array}$ & $\begin{array}{l}\text { School } \\
\text { principal self- } \\
\text { efficacy, } \\
\text { Instructional } \\
\text { leadership } \\
\text { Engagement, } \\
\text { emotional } \\
\text { exhaustion } \\
\text { and } \\
\text { motivation }\end{array}$ & $\begin{array}{l}\text { SEM } \\
\text { Analysis, } \\
\text { with } 340 \\
\text { principal as } \\
\text { the samples }\end{array}$ & $\begin{array}{l}\text { Self-efficacy is } \\
\text { negatively related to } \\
\text { instructional leadership } \\
\text { and emotional } \\
\text { exhaustion. Self- } \\
\text { efficacy is positively } \\
\text { related to engagement } \\
\text { Self-efficacy is } \\
\text { negatively related to } \\
\text { quitting intentions } \\
\text { mediated by emotional } \\
\text { exhaustion and } \\
\text { engagement }\end{array}$ \\
\hline
\end{tabular}

Teacher motivation is related to instructional leadership and the weakest is creating a good learning environment.

\begin{tabular}{|c|c|c|c|c|}
\hline 10 & $\begin{array}{l}\text { Skaalvi } \\
\mathrm{k}[74], \\
\text { Norwa } \\
\mathrm{y}\end{array}$ & $\begin{array}{l}\text { Self-efficacy, } \\
\text { instructional } \\
\text { leadership, } \\
\text { perceived job } \\
\text { demands, job } \\
\text { resources, } \\
\text { emotional } \\
\text { exhaustion, } \\
\text { job } \\
\text { satisfaction, } \\
\text { motivation to } \\
\text { quit }\end{array}$ & $\begin{array}{l}\text { SEM, with } \\
447 \text { samples }\end{array}$ & $\begin{array}{l}\text { Negatively related self- } \\
\text { efficacy for instructional } \\
\text { leadership to job } \\
\text { demands but positively } \\
\text { related to perceptions of } \\
\text { job resources. Self- } \\
\text { efficacy, emotional } \\
\text { exhaustion, job } \\
\text { satisfaction, and } \\
\text { intention to quit are } \\
\text { mediated by job } \\
\text { demands and job } \\
\text { resources. }\end{array}$ \\
\hline
\end{tabular}




\begin{tabular}{|c|c|c|c|c|}
\hline 11 & $\begin{array}{l}\text { Skapin } \\
\text { aki and } \\
\text { Salamo } \\
\text { ura } \\
\text { [75], } \\
\text { Greece }\end{array}$ & $\begin{array}{l}\text { Teachers' } \\
\text { self-efficacy } \\
\text { and } \\
\text { satisfaction }\end{array}$ & $\begin{array}{l}\text { Multivariate } \\
\text { analysis, with } \\
193 \text { teachers } \\
\text { as the } \\
\text { samples }\end{array}$ & $\begin{array}{l}\text { Educational } \\
\text { management, social } \\
\text { recognition, and } \\
\text { professional } \\
\text { development related to } \\
\text { parents, students, } \\
\text { infrastructure, nature of } \\
\text { work, and working } \\
\text { conditions. Teacher } \\
\text { efficacy measures } \\
\text { related to classroom } \\
\text { relationship } \\
\text { management, student, } \\
\text { and engagement } \\
\text { strategies. }\end{array}$ \\
\hline 12 & $\begin{array}{l}\text { Toulou } \\
\text { pis and } \\
\text { Athana } \\
\text { siades } \\
\text { [76], } \\
\text { Greece, } \\
\text { Central } \\
\text { Maced } \\
\text { onia } \\
\text { and } \\
\text { Attica }\end{array}$ & $\begin{array}{l}\text { Primary } \\
\text { school } \\
\text { principals', } \\
\text { teachers' } \\
\text { perceptions of } \\
\text { students' } \\
\text { online risk } \\
\text { behaviors, } \\
\text { perceived } \\
\text { self-efficacy }\end{array}$ & $\begin{array}{l}\text { Exploratory } \\
\text { analysis } \\
\text { factor and the } \\
\text { Varimax type } \\
\text { rotation, 237 } \\
\text { principals and } \\
295 \text { teachers }\end{array}$ & $\begin{array}{l}\text { Principal self-efficacy } \\
\text { triggers student learning } \\
\text { and ethical behavior. } \\
\text { Teacher efficacy has an } \\
\text { effect on teachers } \\
\text { managing student } \\
\text { behavior and predicting } \\
\text { perceptions of attitudes } \\
\text { to lessons. }\end{array}$ \\
\hline 13 & $\begin{array}{l}\text { Cusack } \\
{[77],} \\
\text { Canada }\end{array}$ & $\begin{array}{l}\text { Self-Efficacy } \\
\text { of Assistant } \\
\text { Principals, } \\
\text { Patterns, } \\
\text { Trends, and } \\
\text { Challenges }\end{array}$ & $\begin{array}{l}\text { Survey, } \\
\text { Instructional } \\
\text { (LQS) Use of } \\
\text { PSES, with } \\
101 \text { principal } \\
\text { as the } \\
\text { samples } \\
\end{array}$ & $\begin{array}{l}\text { The vice principal's } \\
\text { leadership experience } \\
\text { affects the perception of } \\
\text { success as a school } \\
\text { principal }\end{array}$ \\
\hline 14 & $\begin{array}{l}\text { Valckx } \\
\text { Vander } \\
\text { linde } \\
{[78],} \\
\text { Belgiu } \\
\mathrm{m}\end{array}$ & $\begin{array}{l}\text { Transformatio } \\
\text { nal } \\
\text { leadership, } \\
\text { teacher } \\
\text { autonomy, } \\
\text { and teachers' } \\
\text { self-efficacy }\end{array}$ & $\begin{array}{l}\text { Path analysis, } \\
324 \text { teachers } \\
\text { in } 80 \text { of } 33 \\
\text { secondary } \\
\text { schools }\end{array}$ & $\begin{array}{l}\text { Positively, shared } \\
\text { responsibility and } \\
\text { teacher self-efficacy are } \\
\text { related to reflective } \\
\text { activities. self-efficacy } \\
\text { mediates teacher } \\
\text { autonomy and reflective } \\
\text { activity }\end{array}$ \\
\hline 15 & $\begin{array}{l}\text { Weissb } \\
\text { lueth } \\
\text { and } \\
\text { Linder } \\
\text { [79], } \\
\text { Israel }\end{array}$ & $\begin{array}{l}\text { The Effects of } \\
\text { Simulations } \\
\text { on Principals' } \\
\text { Training and } \\
\text { Professional } \\
\text { Self-Efficacy }\end{array}$ & $\begin{array}{l}\text { EFA \& CFA, } \\
\text { with } 22 \\
\text { Principal } \\
\text { training as the } \\
\text { samples }\end{array}$ & $\begin{array}{l}\text { The post-test found a } \\
\text { positive correlation } \\
\text { between the age of } \\
\text { students' professional } \\
\text { self-efficacy elements }\end{array}$ \\
\hline 16 & $\begin{array}{l}\text { CCoban, } \\
\text { Özdem } \\
\text { ir [80], } \\
\text { Turkey }\end{array}$ & $\begin{array}{l}\text { Trust in } \\
\text { principals, } \\
\text { leaders' } \\
\text { focus, teacher } \\
\text { collaboration, } \\
\text { and teacher } \\
\text { self-efficacy: }\end{array}$ & $\begin{array}{l}\text { Survey, } \\
18,745 \\
\text { teachers }\end{array}$ & $\begin{array}{l}\text { Teachers' trust in } \\
\text { principals influences } \\
\text { teaching and principals' } \\
\text { instructional leadership } \\
\text { practices increase } \\
\text { teacher self-efficacy } \\
\text { directly and indirectly } \\
\text { mediated by teacher } \\
\text { collaboration }\end{array}$ \\
\hline
\end{tabular}

Source: Data Analysis 2021

\section{FINDINGS / RESULTS}

The authors present the results and discussion based on the order of the research questions. The following is the explanation.

RQ 1, "What does self-efficacy affect in terms of leadership and leadership affects self-efficacy?" There is a statistically important connection among transformational leadership style, teacher self-efficacy, transformational management and educator self-efficacy. A statistically, there was an important connection between transactional management style and educator self-efficacy. It was found that an absolute connection existed between self-efficacy and the affective dedication of leaders. Furthermore, there was an absolute affiliation between self-efficacy and a leader's sustainability dedication. Leadership self-efficacy absolutely relates to mutual dedication. The investigation released that self-efficacy for teaching management was negatively connected to psychological fatigue.

The analysis clothed that self-efficacy was also absolutely connected to engagement, suggesting that the validity of a good scale criterion was negatively connected to boost to leave. The measurement of self-efficacy for teaching management was highly closely related to psychological fatigue and involvement in motivating educators. Self-efficacy for teaching management was negative associated with perceptions of all employment requests and absolutely related to perceptions of all job resources in this study. However, compared to teachers, principals at higher levels felt confident about managing these problems and supporting the participation of the school society in precaution/ intervention in them. In addition, the principal's self-efficacy in boosting student good attitude in schools and educators' self-efficacy in organizing student behavior matters in the classroom absolutely predict the conceptions of those studied.

Self-efficacy will contribute to the well-being of an institution, namely an effective school. The literature on class effectiveness more the last few decades have prepared proof indicating that principal management plays an important character in class achievement. Researches discuss that leadership practices, whatever the style, such as an effective distributed and instructional leadership style can bolster student learning, moreover while the effect indirect. Leadership supports student achievement through its lineal results on climate, constructions, civilization, values, and educators [8-10]. School leadership in general influences through its influence on people and processes so that school leaders can straightly effect educators' beliefs, feels, and daily activities. For example, study that investigates whether and to what dimensions school management is able to quantify the kinds with regard to job satisfaction and perceptions of selfefficacy $[11-15,17,18,81]$. This study concludes that leadership and educational outcomes are directly and indirectly related.

Self-efficacy is the confidence in persons who have the ability to perform certain tasks [1]. It is also defined as students' beliefs about their own academic abilities. Perjures described that self-efficacy can effect students' cognition, motivation, effective activity, and behavior [26]. Therefore, in the teaching and studying procedure, student behavior is important in student behavior to achieve learning. Self-efficacy which plays a character in the self-regulation process that can influence students' choice psychologically to complete tasks. In line with Bandura, Pintrich and De Groot stated that students' self-efficacy of the top of the ability is the basis for self-confidence and motivation to outplay in their jobs [27]. Self-efficacy by four elements: past experiences of success and failure, experiences of representation or modeling, where management of success and failure attends to upgrade or 
decrease self-efficacy, social seduction (work or dispiritedness) of others, people's beliefs on abilities they are [1]. As a conclusion to this framework, a good headmaster's self-efficacy affects teacher self-efficacy and educator selfefficacy affects student self-efficacy. Good student selfefficacy is directly correlated with student achievement.

RQ2, "What influences self-efficacy inside the structure of leadership practice?" The characteristics of a teacher-centered Professional Student Community, namely collective and shared inquiry and shared goals and responsibilities, significantly and positively affect teacher self-efficacy for learning strategies. The outcomes showed that shared leadership and instructional leadership were absolutely and immediately related to educator satisfaction. Leadership has a positive and roundabout relationship with educator work contentment and self-efficacy. There is a statistically significant relationship among transformational management style and educator self-efficacy and among transaction leadership style and educator self-efficacy.

It was established that an absolute connection existed among self-efficacy and affective appointment of leaders. In addition, a good affiliation between self-efficacy and a leader's sustainability commitment. The goals of organizational support are aligned with and bolster the self-efficacy of colored headmistress who leads turnarounds. The measurement of self-efficacy for teaching management was highly close related to psychological fatigue and involvement was self-efficacy for motivating educators. The element of instructional leadership that was the weakest connected to these modifiable is self-efficacy to create good and secure studying surroundings for learners. A person's willingness to comply with all the rules and agreements is known as normative commitment. Furthermore, because he hopes to be of use to others and has the courage to decide to abide by the rules, he has the courage to leave personal transactional interests centered on self-interest. A person's willingness to continue to be in the organization is known as continuous commitment (CC) [82].

Pedagogical leadership, community admission, and expertise growth, relations with parents and students, infrastructure and working situations and environment of work, whilst class and student relationship management and "student involvement and education planes influence the measurements of teacher self-efficacy. However, compared to educators, principals at higher levels felt confident about managing this problem and supporting the involvement of the school community in prevention / intervention in it. The mutual commitment and self-efficacy of teachers are absolutely linked to their reflective dialogue. Firm good links were established between student length of life and each of the measurable factors of Professional Self-Efficacy in the post-test. This research ensures the previous study, which suggests that belief in school principals has an important role in teacher tension on teaching and that these headmaster's teaching management increase teacher feelings of success both immediately and through educator teamwork indirectly.

It is clear lest principal leadership, school practice, and educator outcomes thick show in separated studies. There is little proof of how principal leadership regulates the school scene to realize the hoped for educator outcomes. Goddard, Goddard, Kim, and Miller emphasized that teaching management applications are very important to create a surrounding where educators could study to another [83]. The finding of teaching management bolsters the learning circumstances with the teamwork of teachers who are prosperous and mutually respectful, and it is helpful to increasing self-efficacy and job happiness [84]. However, instructional management has also taken criticism because it is still representative of a top-down and heroic leadership manner $[85,86]$. Such a leadership style might allow educators more as commanders than functioning agents of change for school advance. In contrast, distributed leadership involves the headmaster's portion management with educators and other people in concern. When educators own a further vote in schools, they can take more commitment to leading school transformation and development [87, 88]. Authorizing educators will make an environment in which educators tend to cooperate for preferable school results and reach better job satisfaction [81]. Evidence suggests that the two models of leadership have different emphases, arguably giving different levels of teacher outcomes thru certain conditions, yet this proof cannot be obtained easily.

Self-efficacy can develop. The cultivation of self-efficacy is influenced by one's past involvements in and is stored as preexisting knowledge and events that are perceived as social bolster taken from others that occur in the surrounding environment [47]. When someone participates in an activity, their level of involvement is related to the distorted elements from whose they get indications that indicate the successfulness of their achievement. Self-motivation is expanded and increased when personals feel that their competence to do tasks increases and they become more competent in achieving specified goals [47]. Once society are boosted, they are still have a tendency to be involved in the task, and by turn, their feeling of self-efficacy is still possible to be well affected. That is especially the matter when individuals are given up date assignments for which they possess a shortage of references to previous experiences. Persons obtain cues throughout the involvement procedure to assist evolve their feeling of stimulus from which they establish confidences of their ability to perform tasks [48]. Highly motivated people are still probable to maintain a supreme level of involvement in a job for a greater span of time than somebody who is less boosted, and so they are more possible to reach set purposes [48]. Hence, the grade of involvement works as a significant factor of self-efficacy growth.

RQ 3, "What is self-efficacy of mediation in the framework of leadership practice?" Based on constructional similarities modeling, the principal's leadership has an important indirect effect on educators teamwork, mediated by the collective efficacy of educators. Self-efficacy mediates the effect of instructional management on professional competence. The goals of organizational support are aligned. Transformational leadership is well affiliated with educator mastery goals and self-efficacy. Both mediate in part the connection among 
transformational leadership.

The analysis revealed that self-efficacy. The analysis expressed that self-efficacy was self-efficacy too. This relationship is indirect and moderated by means of emotional exhaustion and self-efficacy involvement. In SEM analysis, the relationship among self-efficacy and psychological fatigue, work attainment, and boost to leave was mediated via perceptions of employment requests and employment assets circumstantially. The concept of involvement is learned in trade, psychology, and schooling and is connected with selfencouragement $[49,50]$. Although there is no commonly used certainty or general construction that describes the idea, it is commonly approved that involvement is related to the existence of emotional and emotional conditions when a person takes organizational missions [51]. Therefore, we conceptualize involvement as comprising two main elements: perceptive involvement (a person's compliant to do something towards the achievement of purposes) and conduct involvement (person's tactics in attaining purposes).

Pedagogical involvement requires a person's perceptual expenditure in studying comprising framing the effort obligatory to understand the task [52]. Behavioral engagement deals with the measures and applications required for engagement in carrying out a specific goal-oriented task [53]. Engaged workers lean to work at high grades because they trust their job has important [54]. Additionally, people who are over compliant to spend time in their work and are smaller possible to involve in work destruction. Conversely, uninvolved workers lean to show a deficit of inner individual attention and are still possible to involve in self-uncertainty in fruitfulness taking out group characters [51]. Workers who engaged could learn from, and be boosted by, situational effects like purpose setting and receive news, and display the response in the environment [47]. Moreover, this news and response design their capability to take institutional significant characters to them [54], Whose in turn facilitates their construction of self-efficacy [48]. Moreover, this news and response design their capability to take institutional significant characters to them [54], which by turn facilitates their construction of self-efficacy.

Community web concept is interested with the designs of connections among workers (e.g., persons, class, organization), and the outcoming relation positions of workers (e.g., inner, outer, intermediary) [56, 57]. A community web is composed by a group of workers and the relational relationships among the actors that explain the network [58]. The position of actor-network is determined by the system of relatively bonds that actors in the network have [57, 59]. Social networks can be utilized to establish the community capital of personal workers. This idea is a basis of the conceptual opinion that related leaps are invested in community relationships among workers in web contractions and could be collected and thrown across networks to increase the likelihood of success in action [59]. This social capital network perspective also discusses the constructions of social connections that encircle workers and the outcoming web positions of personal workers who can bolster or limit the movement of assets between these workers [62, 63]. In general, networking experts posit that tightly connected network structures can make easy or limit the entrance and timing of news and the stream of community resources over networks [59]. Whilst a solid web contraction allows assets to travel efficiently over the web, it can ease and amplify assets that take bad effects like rumors, hostility, and mistrust too [64].

\section{CONCLUSION}

Based on the articles reviewed, we can know the connection among principal leadership and self-efficacy. The authors draw the following conclusions: 1) Self-efficacy affects variables including motivation not to resign, emotional exhaustion, job satisfaction, and normative commitment. 2) Self-efficacy can fluctuate, influenced by the leadership style of the principal, school climate, school culture, and the opinions of people around. 3) Self-efficacy can be a mediator for the growth and development of other variables.

\section{RECOMMENDATIONS}

Referring to the discoveries in this investigation, we recommend for further researchers and practitioners: As long as a person is a leader, he should consider the teacher and staff efficacy factor because self-efficacy can influence and be influenced. So that the course of the leadership wheel in order to achieve organizational goals is easier to achieve.

\section{LIMITATIONS}

The majority of this study examined studies relating to the self-efficacy of principals conducted in Europe, and a small portion of Asia and America. This article has not discussed much of the principal self-efficacy of studies conducted in Africa and Australia. It would be nice for further research to include these two areas.

\section{ACKNOWLEDGEMENTS}

With humility and high respect, the authors would like to thank and respect all researchers who have conducted research and provided an abundant source of knowledge. We have no dispute of benefit in this study.

\section{REFERENCES}

[1]. Bandura, A., Self-efficacy. The Corsini encyclopedia of psychology, 2010: p. 1-3.

[2]. Bandura, A., Perceived self-efficacy in cognitive development and functioning. Educational psychologist, 1993. 28(2): p. 117-148.

[3]. Skaalvik, E.M. and S. Skaalvik, Dimensions of teacher selfefficacy and relations with strain factors, perceived collective teacher efficacy, and teacher burnout. Journal of educational psychology, 2007. 99(3): p. 611.

[4]. Tschannen-Moran, M. and A.W. Hoy, Teacher efficacy: Capturing an elusive construct. Teaching and teacher education, 2001. 17(7): p. 783-805.

[5]. Skaalvik, E.M. and S. Skaalvik, Teacher self-efficacy and perceived autonomy: Relations with teacher engagement, job satisfaction, and emotional exhaustion. Psychological reports, 2014. 114(1): p. 68-77.

[6]. Bandura, A., The anatomy of stages of change. American journal of health promotion: AJHP, 1997. 12(1): p. 8-10. 
[7]. Goddard, R.D., M. Tschannen-Moran, and W.K. Hoy, A multilevel examination of the distribution and effects of teacher trust in students and parents in urban elementary schools. The elementary school journal, 2001. 102(1): p. 3-17.

[8]. Hallinger, P. and R.H. Heck, Exploring the principal's contribution to school effectiveness: 1980-1995. School effectiveness and school improvement, 1998. 9(2): p. 157-191.

[9]. Heck, R.H. and P. Hallinger, Assessing the contribution of distributed leadership to school improvement and growth in math achievement. American educational research journal, 2009. 46(3): p. 659-689.

[10]. Robinson, V.M., C.A. Lloyd, and K.J. Rowe, The impact of leadership on student outcomes: An analysis of the differential effects of leadership types. Educational administration quarterly, 2008. 44(5): p. 635-674.

[11]. Bogler, R., The influence of leadership style on teacher job satisfaction. Educational administration quarterly, 2001. 37(5): p. 662-683.

[12]. Duyar, I., S. Gumus, and M.S. Bellibas, Multilevel analysis of teacher work attitudes. International Journal of Educational Management, 2013.

[13]. Gedik, S. and M.S. Bellibas, Examining Schools' Distributed Instructional Leadership Capacity: Comparison of Elementary and Secondary Schools. Journal of Education and Training Studies, 2015. 3(6): p. 101-110.

[14]. Hallinger, P. and A. Walker, Leading learning in Asia-emerging empirical insights from five societies. Journal of Educational Administration, 2017.

[15]. Hulpia, H., G. Devos, and Y. Rosseel, The relationship between the perception of distributed leadership in secondary schools and teachers' and teacher leaders' job satisfaction and organizational commitment. School Effectiveness and School Improvement, 2009. 20(3): p. 291-317.

[16]. Liu, Y. and S.M. Printy, Open the Black Box of Distributed Leadership: Evidence from the 2013 TALIS. AERA Online Paper Repository, 2017.

[17]. Ngotngamwong, R., $\square \square \square \square$ ไป ใน โลก กว้าง แห่ง อาชีพ เลขานการ และ ผ้ ช่วย ฝ่าย ธุรการ. Business Review Journal, 2018. 10(2): p. 23-38.

[18]. Nir, A.E. and N. Kranot, School Principal's Leadership Style and Teachers' Self-Efficacy. Planning and Changing, 2006. 37: p. 205218.

[19]. Goddard, J.M. and J. Hotchkiss, Polymer surface modification for the attachment of bioactive compounds. Progress in polymer science, 2007. 32(7): p. 698-725.

[20]. Chong, T.K., et al., Optimal wavelength scale diffraction gratings for light trapping in solar cells. Journal of Optics, 2012. 14(2): p. 024012.

[21]. Shachar, H. and H. Shmuelevitz, Implementing cooperative learning, teacher collaboration and teachers' sense of efficacy in heterogeneous junior high schools. Contemporary educational psychology, 1997. 22(1): p. 53-72.

[22]. Woods, A.M. and J. Weasmer, Maintaining job satisfaction: Engaging professionals as active participants. The Clearing House, 2004. 77(3): p. 118-121.

[23]. Graham, S. and D. Perin, A meta-analysis of writing instruction for adolescent students. Journal of educational psychology, 2007. 99(3): p. 445

[24]. Liu, Y. and M.S. Bellibas, School factors that are related to school principals' job satisfaction and organizational commitment. International Journal of Educational Research, 2018. 90: p. 1-19.

[25]. Ngo, L.T.H., et al., Breastfeeding self-efficacy and related factors in postpartum Vietnamese women. Midwifery, 2019. 70: p. 84-91.

[26]. Pajares, F., Gender and perceived self-efficacy in self-regulated learning. Theory into practice, 2002. 41(2): p. 116-125.

[27]. Pintrich, P.R. and E.V. De Groot, Motivational and self-regulated learning components of classroom academic performance. Journal of educational psychology, 1990. 82(1): p. 33.

[28]. Leithwood, K. and D. Jantzi, Linking leadership to student learning: The contributions of leader efficacy. Educational administration quarterly, 2008. 44(4): p. 496-528.
[29]. Tschannen- Moran, M. and C.R. Gareis, Principals' sense of efficacy: Assessing a promising construct. Journal of Educational administration, 2004.

[30]. Schmidt, A.M. and R.P. DeShon, Prior performance and goal progress as moderators of the relationship between self-efficacy and performance. Human Performance, 2009. 22(3): p. 191-203.

[31]. Tims, M., A.B. Bakker, and D. Derks, Daily job crafting and the self-efficacy-performance relationship. Journal of Managerial Psychology, 2014.

[32]. Bates, A.B., N. Latham, and J.a. Kim, Linking preservice teachers' mathematics Self-Efficacy and mathematics teaching efficacy to their mathematical performance. School Science and Mathematics, 2011. 111(7): p. 325-333.

[33]. Lewis, J.L., et al., Con cariño: Teacher caring, math self-efficacy, and math achievement among Hispanic English learners. Teachers College Record, 2012. 114(7): p. 1-42.

[34]. Stipek, D., Context matters: Effects of student characteristics and perceived administrative and parental support on teacher selfefficacy. The Elementary School Journal, 2012. 112(4): p. 590606.

[35]. Federici, R.A. and E.M. Skaalvik, Principal self-efficacy: Relations with burnout, job satisfaction and motivation to quit. Social Psychology of Education, 2012. 15(3): p. 295-320.

[36]. Liou, Y.-H., Tied to the Common Core: Exploring the characteristics of reform advice relationships of educational leaders. Educational Administration Quarterly, 2016. 52(5): p. 793-840.

[37]. Daly, A.J. and K.S. Finnigan, The challenge of school and district improvement: Promising directions in district reform. Thinking and acting systemically: Improving school districts under pressure, 2016: p. 229-242.

[38]. Honig, M.I., District central office leadership as teaching: How central office administrators support principals' development as instructional leaders. Educational Administration Quarterly, 2012. 48(4): p. 733-774.

[39]. Bandura, A., Social cognitive theory in cultural context. Applied psychology, 2002. 51(2): p. 269-290.

[40]. Woulfin, S.L., M.L. Donaldson, and R. Gonzales, District leaders' framing of educator evaluation policy. Educational Administration Quarterly, 2016. 52(1): p. 110-143.

[41]. Seashore Louis, K., B. Dretzke, and K. Wahlstrom, How does leadership affect student achievement? Results from a national US survey. School effectiveness and school improvement, 2010. 21(3): p. 315-336.

[42]. McCullers, J. and W. Bozeman, Principal self-efficacy: The effects of No Child Left Behind and Florida school grades. Nassp Bulletin, 2010. 94(1): p. 53-74.

[43]. Polikoff, M.S. and A.C. Porter, Instructional alignment as a measure of teaching quality. Educational Evaluation and Policy Analysis, 2014. 36(4): p. 399-416.

[44]. Bandura, A., Comments on the crusade against the causal efficacy of human thought. Journal of behavior therapy and experimental psychiatry, 1995. 26(3): p. 179-190.

[45]. Greene, B.A. and R.B. Miller, Influences on achievement: Goals, perceived ability, and cognitive engagement. Contemporary Educational Psychology, 1996. 21(2): p. 181-192.

[46]. Pajares, F., Self-efficacy beliefs in academic settings. Review of educational research, 1996. 66(4): p. 543-578.

[47]. Schunk, D.H., Self-efficacy and education and instruction, in Selfefficacy, adaptation, and adjustment. 1995, Springer. p. 281-303.

[48]. Schunk, D.H., Social cognitive theory and self-regulated learning, in Self-regulated learning and academic achievement. 1989, Springer. p. 83-110.

[49]. Parker, S.L., N.L. Jimmieson, and C.E. Amiot, The stress-buffering effects of control on task satisfaction and perceived goal attainment: An experimental study of the moderating influence of desire for control. Applied psychology, 2009. 58(4): p. 622-652.

[50]. Saks, A.M., Antecedents and consequences of employee engagement revisited. Journal of Organizational Effectiveness: People and Performance, 2019. 
[51]. Kahn, W.A., Psychological conditions of personal engagement and disengagement at work. Academy of management journal, 1990. 33(4): p. 692-724.

[52]. Wang, M.-T. and J.S. Eccles, School context, achievement motivation, and academic engagement: A longitudinal study of school engagement using a multidimensional perspective. Learning and Instruction, 2013. 28: p. 12-23.

[53]. Connell, J.P., Context, self, and action: A motivational analysis of self-system processes across the life span. The self in transition: Infancy to childhood, 1990. 8: p. 61-97.

[54]. May, D.R., R.L. Gilson, and L.M. Harter, The psychological conditions of meaningfulness, safety and availability and the engagement of the human spirit at work. Journal of occupational and organizational psychology, 2004. 77(1): p. 11-37.

[55]. Zhu, W., D.R. May, and B.J. Avolio, The impact of ethical leadership behavior on employee outcomes: The roles of psychological empowerment and authenticity. Journal of Leadership \& Organizational Studies, 2004. 11(1): p. 16-26.

[56]. Borgatti, S.P., Centrality and network flow. Social networks, 2005. 27(1): p. 55-71.

[57]. Scott, A.J., The cultural economy of cities: essays on the geography of image-producing industries. 2000: Sage.

[58]. Wasserman, S. and K. Faust, Social network analysis: Methods and applications. 1994.

[59]. Burt, R.S., Closure as social capital. Social capital: Theory and research, 2001: p. 31-55.

[60]. Coleman, K.M., Fatal charades: Roman executions staged as mythological enactments. The Journal of Roman Studies, 1990. 80: p. 44-73.

[61]. Lin, J. and H.J. Chang, Should Industrial Policy in developing countries conform to comparative advantage or defy it? A debate between Justin Lin and Ha-Joon Chang. Development policy review, 2009. 27(5): p. 483-502.

[62]. Borgatti, S.P. and P.C. Foster, The network paradigm in organizational research: A review and typology. Journal of management, 2003. 29(6): p. 991-1013.

[63]. Cross, R., S.P. Borgatti, and A. Parker, Making invisible work visible: Using social network analysis to support strategic collaboration. California management review, 2002. 44(2): p. 2546.

[64]. Grosser, T.J., V. Lopez-Kidwell, and G. Labianca, A social network analysis of positive and negative gossip in organizational life. Group \& Organization Management, 2010. 35(2): p. 177-212.

[65]. Zhang, J., H. Yin, and T. Wang, Exploring the effects of professional learning communities on teacher's self-efficacy and job satisfaction in Shanghai, China. Educational Studies, 2020: p. $1-18$.

[66]. Liu, Y., M.S. Bellibas, and S. Gümüs, The effect of instructional leadership and distributed leadership on teacher self-efficacy and job satisfaction: Mediating roles of supportive school culture and teacher collaboration. Educational Management Administration \& Leadership, 2020: p. 1741143220910438.

[67]. Meyer, A., D. Richter, and V. Hartung-Beck, The relationship between principal leadership and teacher collaboration: Investigating the mediating effect of teachers' collective efficacy. Educational Management Administration \& Leadership, 2020: p. 1741143220945698

[68]. Phyu, L.K., H. Khin, and N.N. Htwe, PRINCIPAL LEADERSHIP STYLE AND TEACHER SELF-EFFICACY IN BASIC EDUCATION HIGH SCHOOLS. 2020.

[69]. Herawati, R. and H.K. Tjahjono, The Influence of Instructional Leadership on Professional Competence Mediated by SelfEfficacy and Social Capital. Jurnal Manajemen Bisnis, 2020. 11(2): p. 202-213.

[70]. Almutairi, Y.M.N., Leadership Self-Efficacy and Organizational Commitment of Faculty Members: Higher Education. Administrative Sciences, 2020. 10(3): p. 66.

[71]. Harrison, O., Removing the Lens of Bias: Promoting Self-Efficacy of Black Female Leaders in Turnaround Schools through Organizational Systems. 2020.
[72]. Luo, W., et al., Transformational leadership and its relations to teacher outcomes in Singapore: Mastery goals and self-efficacy as mediators. Leadership and Policy in Schools, 2020: p. 1-17.

[73]. Skaalvik, C., School principal self-efficacy for instructional leadership: relations with engagement, emotional exhaustion and motivation to quit. Social Psychology of Education, 2020: p. 1-20.

[74]. Skaalvik, C., Self-efficacy for instructional leadership: relations with perceived job demands and job resources, emotional exhaustion, job satisfaction, and motivation to quit. Social Psychology of Education, 2020. 23(5): p. 1343-1366.

[75]. Skapinaki, A. and M. Salamoura, Investigating primary school quality using teachers' self-efficacy and satisfaction. Journal of Tourism, Heritage \& Services Marketing (JTHSM), 2020. 6(1): p. 17-24.

[76]. Touloupis, T. and C. Athanasiades, A comparison between primary school principals' and teachers' perceptions of students' online risk behaviours: the role of perceived self-efficacy. Cambridge Journal of Education, 2020. 50(4): p. 1-18.

[77]. Cusack, T.P., Understanding the Self-Efficacy of Assistant Principals in an Urban School Division: Patterns, Trends, and Challenges to Be Mastered. 2020.

[78]. Valckx, J., R. Vanderlinde, and G. Devos, Departmental PLCs in secondary schools: the importance of transformational leadership, teacher autonomy, and teachers' self-efficacy. Educational Studies, 2020. 46(3): p. 282-301.

[79]. Weissblueth, E. and I. Linder, The Effects of Simulations in a Simulation Center on Principals' Training and Professional SelfEfficacy. International Journal of Education Policy and Leadership, 2020. 16(14).

[80]. Çoban, Ö., N. Özdemir, and M.Ş. Bellibaş, Trust in principals, leaders' focus on instruction, teacher collaboration, and teacher self-efficacy: testing a multilevel mediation model. Educational Management Administration \& Leadership, 2020: p. 1741143220968170.

[81]. Liu, Y. and S. Printy, Distributed leadership and educator attitudes. Emerging issues and trends in education, 2017: p. 143180.

[82]. Maydiantoro, A., et al., A Literature Review of the Three Elements of Organizational Commitment: The Meaning of the Contribution Score Average. WSEAS TRANSACTIONS ON BUSINESS AND ECONOMICS, 2021. 18: p. 679-689.

[83]. Goddard, R., et al., A theoretical and empirical analysis of the roles of instructional leadership, teacher collaboration, and collective efficacy beliefs in support of student learning. American Journal of Education, 2015. 121(4): p. 501-530.

[84]. Bellibas, M.S. and Y. Liu, Multilevel analysis of the relationship between principals' perceived practices of instructional leadership and teachers' self-efficacy perceptions. Journal of Educational Administration, 2017.

[85]. Hallinger, P. and R. Heck, Can leadership enhance school effectiveness. Educational management: Redefining theory, policy and practice, 1999: p. 178-190.

[86]. Spillane, J.P. Distributed leadership. in The educational forum. 2005. Taylor \& Francis.

[87]. Harris, A. and J. Spillane, Distributed leadership through the looking glass. Management in education, 2008. 22(1): p. 31-34.

[88]. Lashway, L., The landscape of school leadership. School leadership: Handbook for excellence in student learning, 2006: p. $18-37$.

Tubagus Ali Rachman Puja Kesuma was born in Central Lampung on August 23, 1988. In 2010 he obtained a bachelor's degree in civic education and magister social science education two years later at the University of Lampung, Bandar Lampung city, Indonesia. The author is active in teaching, research, and community service in the scientific field of social science education.

$\mathrm{He}$ is actively working at IAIN Metro Lampung Indonesia as a lecturer in the field of social science education. Some of the international publications produced include: 
1. Kesuma, T. A. R. P., Ciciria, D., \& Purwasih, A. (2020, August). The Development of Local Wisdom and Islamic Values-Based Democratic Material in IAIN Metro. In International Conference On Social Studies, Globalisation And Technology (ICSSGT 2019) (pp. 58-66). Atlantis Press.

2. Kesuma, T. A. R. P., \& Ayyuhda, C. (2020). Social Studies Learning Based On Local Wisdom Values In Lampung. In The 4th International Seminar on Social Studies and History Education (ISSSHE) (pp. 132-146). School of Postgraduate Studies Study Program of Social Studies Education Universitas Pendidikan Indonesia

3. Maydiantoro, A., Tusianah, R., Isnainy, U. C., Kesuma, T. A. R. P, Zainaro, M. A., \& Nurmalisa, Y. (2021). A Literature Review of the Three Elements of Organizational Commitment: The Meaning of the Contribution Score Average. WSEAS Transactions on Business And Economics, 18, 679-689.

Tubagus Ali Rachman Puja Kesuma, M.Pd is currently also in the association of social science education study programs throughout Indonesia (APRIPSI).
Creative Commons Attribution License 4.0 (Attribution 4.0 International, CC BY 4.0)

This article is published under the terms of the Creative Commons Attribution License 4.0

https://creativecommons.org/licenses/by/4.0/deed.en US 